\title{
In situ acetylene reduction activity of Scytonema julianum in Vapor cave (Spain)
}

\author{
Antonia Dolores Asencio ${ }^{1}$ and Marina $\mathrm{Aboal}^{2}$
}

\begin{abstract}
:
Asencio A.D., Aboal M. 2011. In situ acetylene reduction activity of Scytonema julianum in Vapor cave (Spain). International Journal of Speleology, 40 (1), 17-21. Tampa, FL (USA). ISSN 0392-6672. DOI: 10.5038/1827-806X.40.1.3

Nitrogen fixation was measured in situ for the first time by acetylene reduction for a greyish mat composed of Scytonema julianum in cavelike environments. Mat-specific rates (129.9-215.7 nmol C $\mathrm{H}_{4} \mathrm{~m}^{-2} \mathrm{~s}^{-1}$ for daytime fixation and 65.1-120.6 nmol $\mathrm{C}_{2} \mathrm{H}_{4} \mathrm{~m}^{-2} \mathrm{~s}^{-1}$ for nighttime fixation) recorded in the Vapor cave differed considerably due to the energy reserves stored during photosynthesis being exhausted and used in the dark phase. The most influential environmental parameter for nitrogen fixation in the Vapor cave is temperature in the daytime and nighttime fixations. Nitrogen fixation by cyanobacteria may contribute considerably to the overall nitrogen cycle in harsh environments such as caves. Nitrogenase activity in Scytonema julianum was roughly 30 times higher than that of Scytonema mirabile, which also grew in cave environments, which is due to the characteristics of each site. The entrance of Vapour cave (Spain) faces SE, measures $0.75 x$ $0.6 \mathrm{~m}$ and opens to shafts of a total depth of $80 \mathrm{~m}$. Its dimensions and environmental conditions (relative humidity up to $100 \%$; maximum temperature, $43^{\circ} \mathrm{C}$ ) imply that it is isolated from external influences, and that the microclimate differs substantially from that experienced externally. Nitrogen fixation, photon flux density, relative humidity and temperature in the Vapor cave were taken hourly over a 24-hour period in winter.
\end{abstract}

Keywords: caves, cyanobacteria, nitrogen fixation, Scytonema julianum, SE Spain

Received 14 August 2010; Revised 28 September 2010; Accepted 12 October 2010

\section{INTRODUCTION}

Nitrogen is a nutrient that limits the growth of microorganisms in all kinds of environments, especially N-poor ones, like caves where nutrients are provided fundamentally thanks to the visits of certain animals that use caves as shelters (Hill, 1987).

Cyanobacteria are the most abundant phototrophic microorganisms to grow in caves. Most of them have structures called heterocysts in which the enzyme responsible for nitrogen fixation, nitrogenase, is found to protect the enzyme from oxygen since this gas irreversibly inhibits this enzyme (Bothe, 1982). The capacity to fix atmospheric nitrogen allows cyanobacteria to play an important role in extreme environments (Houssman et al., 2006; Zielke et al., 2005).

Scytonema julianum (Meneghini ex Franck) Richter is one of the most abundant cyanobacteria in caves (Hoffmann, 1989). It is an aerophytic, filamentous,

\footnotetext{
${ }^{1}$ División Botánica. Departamento de Biología Aplicada.

Facultad de Ciencias Experimentales. Universidad Miguel Hernández. Campus de Elche. Avenida Universidad, s/n. 03202 Elche, Alicante, Spain.

e-mail: aasencio@umh.es (corresponding author)

2 División Botánica. Departamento de Biología Vegetal.

Facultad de Biología. Universidad de Murcia. Campus de

Espinardo. 30100 Murcia, Spain.

e-mail: maboal@um.es
}

branched, heterocysted species characterized by the presence of calcium carbonate crystals on sheaths. Most authors consider this species as typical of lit walls close to cave openings (Hoffmann, 1989), whereas others have detected it in poorly lit conditions (Aboal et al., 1994).

Scytonema julianum has been studied from morphological (Aboal et al., 1994; Couté \& Bury, 1988; Friedman, 1973; Hoffmann, 1992) and biochemical (Bellezza et al., 2006; Antonopoulou et al., 2002, 2005) viewpoints, but nothing is known about its atmospheric nitrogen fixation capacity.

There are very few previous studies on in situ nitrogen fixation by cyanobacteria in caves (Griffiths et al., 1987; Asencio \& Aboal, 2010), despite its importance owing to the fact that certain environmental factors, which cannot be reproduced in the laboratory, intervene in this process. This research work focuses on investigating the in situ nitrogen fixation capacity of a typical cave species, Scytonema julianum, in special environmental conditions (maximum temperature, $43^{\circ} \mathrm{C}$ and relative humidity up to $100 \%$ ) where it grows.

\section{STUDY AREA}

The Vapor cave (Fig. 1) is located in Alhama (Murcia Region, SE Spain), a municipal area crossed by the Alhama Fault. This Fault is considered one of the most active in the Iberian Peninsula, and is responsible for heating ground waters in this region. 


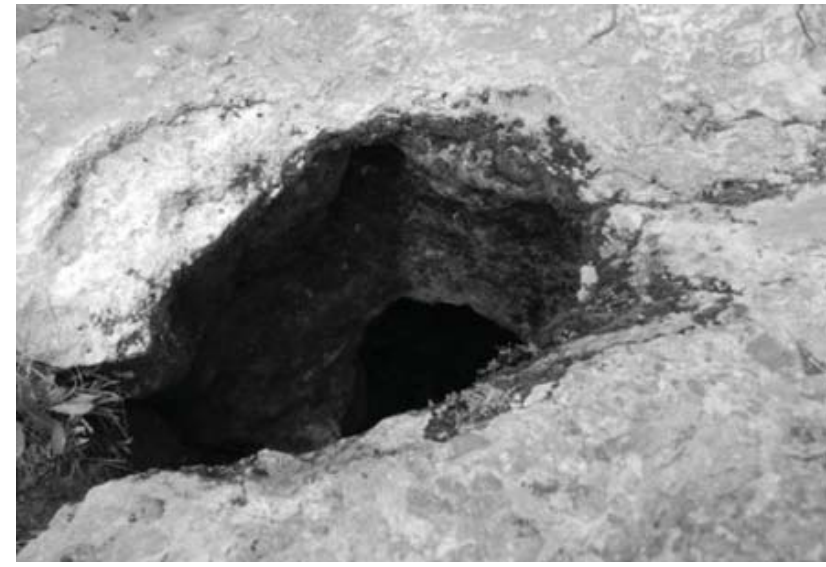

Fig. 1. The Vapor cave entrance in Murcia (SE Spain).

This enclave is located on the Castillo Hill at an altitude of $295 \mathrm{~m}$ (UTM 30SXG389912) and calcite is the dominant mineral $(95 \%)$. At the bottom of this hill we find a warm water spring, used by different civilizations for centuries. The phreatic level of the region has dropped by more than $100 \mathrm{~m}$ over time, and currently the Alhama warm-water spring does not actually flow; but when approaching the Vapor cave a constant steam flow can be observed (Fig. 2).

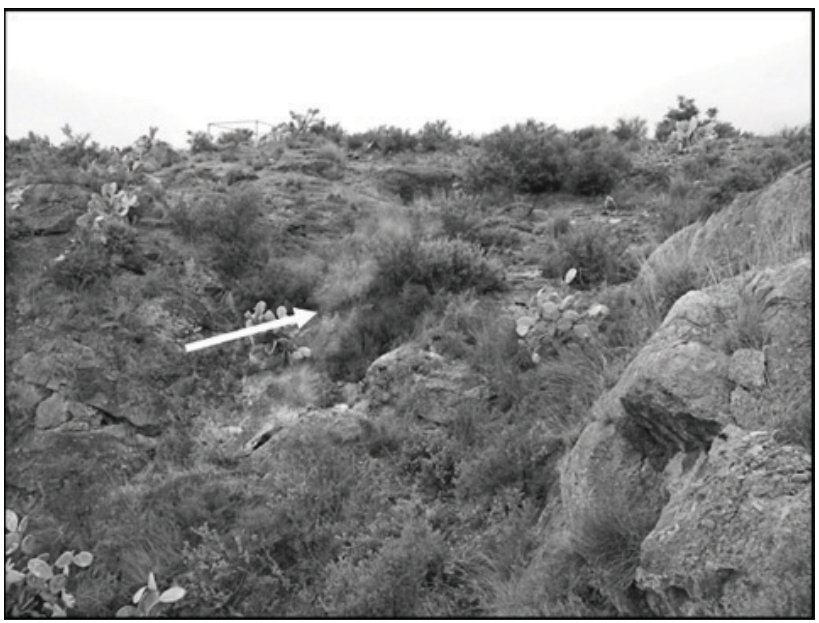

Fig. 2. Panoramic view of Vapor cave with the steam flowing (arrow) from the entrance.

The entrance to this cave, facing $\mathrm{SE}$, is oval-shaped and the axes measure $0.6 \times 0.75 \mathrm{~m}$. It opens to form a diaclase with the strata of conglomerated Triassic limestone edges. Then a small $3.5 \mathrm{~m}$ deep vertical shaft is found in which only plant organisms have been registered. The initial $0.5 \mathrm{~m}$ are covered by bryophytes giving it a greenish tone whereas the following $3 \mathrm{~m}$ are made up of cyanobacteria that create a greyish hue (Fig. 3).

The cave continues over approximately $50 \mathrm{~m}$ along a sharp downward sloping passage, which runs unlevel at $-30 \mathrm{~m}$ in a SE-NW direction until it reaches the top of the Agobio shaft (Fig. 4). This shaft is split in two sections: one measuring $18.30 \mathrm{~m}$ that reaches the Chopard shelf and the other is the bottom measuring $13.70 \mathrm{~m}$. The total shaft length comes to $32 \mathrm{~m}$ where the uneven level lies at $-61.41 \mathrm{~m}$. From this point,

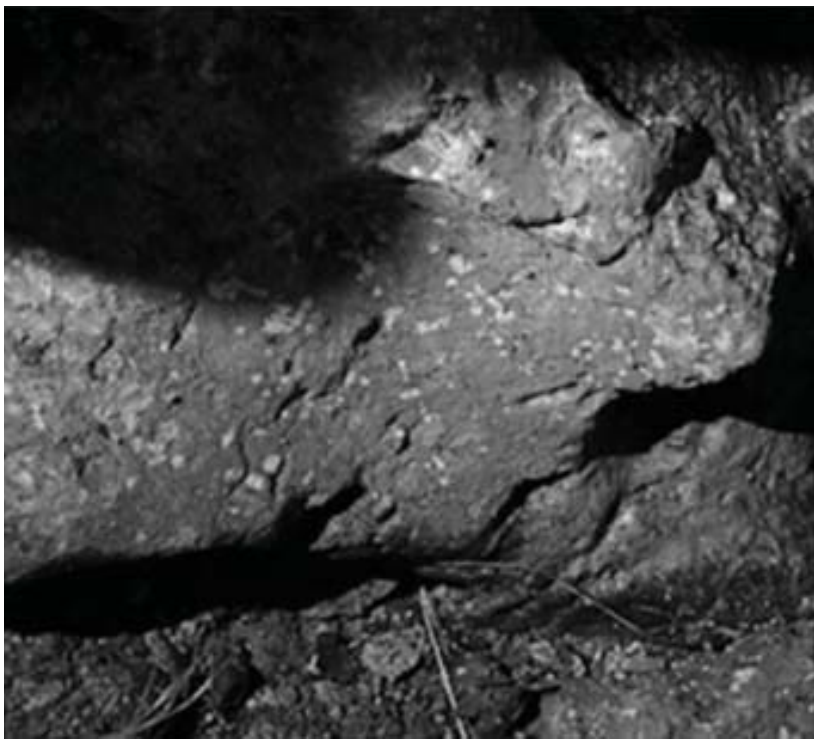

Fig. 3. Wall of Vapor cave showing the Scytonema julianum mat.

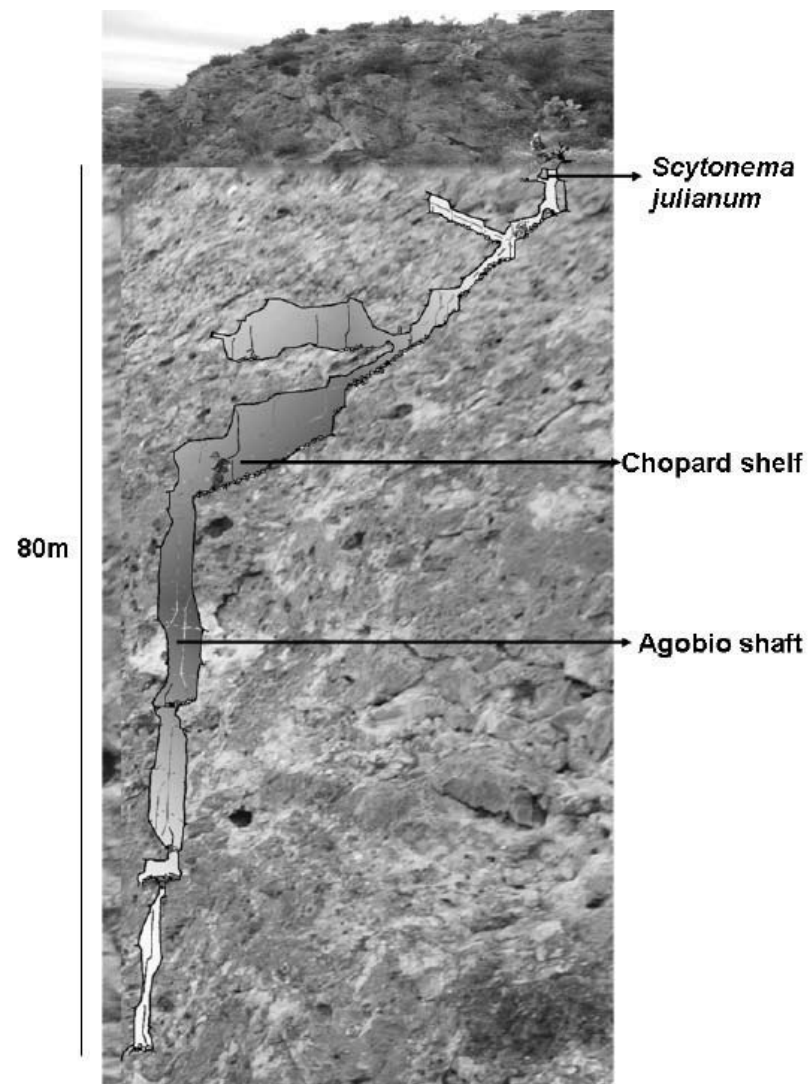

Fig. 4. Drawing showing the different passages and shafts in the Vapor cave.

two descents commence with an uneven level at approximately $-20 \mathrm{~m}$, which places the cavity on a final uneven level of $-80 \mathrm{~m}$.

The relative humidity inside the cavity is $100 \%$. Temperatures vary and increase with depth, ranging between $27^{\circ} \mathrm{C}$ and $43^{\circ} \mathrm{C}$. The carbon dioxide and oxygen concentrations inside the cave are $1.8 \%$ for $\mathrm{CO}_{2}$ and $18.5 \%$ for $\mathrm{O}_{2}$ as opposed to $0.03 \%$ and $20.93 \%$, respectively, recorded in the atmosphere. Given these environmental conditions, the visitors only can access the cave for short periods of time. 


\section{MATERIALS AND METHODS}

Material was collected aseptically from the wall near the Vapor cave opening where Scytonema julianum grows. We were careful not to remain inside too long to avoid any ill effects to our organisms because of the high temperature and high relative humidity of this cave (Ruíz de Almirón, 1998).

Non-hydrated samples were incubated in situ from sunrise to sunset in triplicate inside transparent and opaque sterile vials to reproduce the light and dark conditions, respectively. Then $10 \%$ of the gaseous phase of these vials was replaced with acetylene by placing syringes through the rubber vial stoppers. Gaseous samples were collected on an hourly basis over a 24-hour period in winter between sunrise and sunset. The following values were recorded hourly throughout the incubation period: photon flux density (PAR - photosynthetically active radiation), air temperature and relative humidity. A LI-1400 datalogger model (LICOR) with a LI-192 sensor and a Delta Ohm HD $8501 \mathrm{H}$ thermohygrometre were used. Electrodes were placed on the rock surface. The concentrations of $\mathrm{CO}_{2}$ and $\mathrm{O}_{2}$ in the cave air were measured with a hand pump (Gastec Corporation, Japan) and detector tubes (measurement range: $\mathrm{CO}_{2}$, 300-5,000 ppm; $\mathrm{O}_{2}, 3-24 \%$ ). Nitrogen fixation was quantified by acetylene-ethylene reduction and was subsequently analyzed in a Shimadzu GC 14 A gas chromatograph.

\section{RESULTS}

Nitrogen fixation by Scytonema julianum (Fig. 5), a species growing in the Vapor cave forming a greyish covering, was measured for the first time.

During the daytime, nitrogenase activity ranged between 129.9 and $215.7 \mathrm{nmol}$ of $\mathrm{C}_{2} \mathrm{H}_{4} \mathrm{~m}^{-2} \mathrm{~s}^{-1}$ (Fig. 6). It reached its peak value after a series of high values followed by low values. Thus, the graphic representation of nitrogenase activity is a zigzag pattern. The highest values were recorded at 11:00h, 13:00h and 15:00h at 201.2, 215.7 and $213.0 \mathrm{nmol}$ of $\mathrm{C}_{2} \mathrm{H}_{4} \mathrm{~m}^{-2} \mathrm{~s}^{-1}$, respectively, while the lowest values were observed at 08:00h, 10:00h, 12:00h, 14:00h and $17: 00 \mathrm{~h}$ at $125.1,129.9,157.8$ and $130.4 \mathrm{nmol}$ of $\mathrm{C}_{2}$ $\mathrm{H}_{4} \mathrm{~m}^{-2} \mathrm{~s}^{-1}$, respectively.

The PAR values in the Vapor cave ranged between 5.2 and $57.7 \mu \mathrm{E} . \mathrm{m}^{-2} \cdot \mathrm{s}^{-1}$ (Fig. 7). From 08:00h to 10:00h, these values increased from 7.5 to $18.9 \mu \mathrm{E} \cdot \mathrm{m}^{-2} \cdot \mathrm{s}^{-1}$. Then at this time, a substantial increase took place at 11:00h reaching $48.6 \mu \mathrm{E} \cdot \mathrm{m}^{-2} \cdot \mathrm{s}^{-1}$. Finally, these values continued rising until a peak value of $57.7 \mu \mathrm{E} \cdot \mathrm{m}^{-2} \cdot \mathrm{s}^{-1}$ was noted at 13:00h, to drop later.

The minimum value of relative humidity (Fig. 7) was $72 \%$ recorded at 08:00h. Relative humidity progressively increased to a maximum value of $100 \%$ at $11: 00 \mathrm{~h}$, and remained so until $17: 00 \mathrm{~h}$ when it dropped slightly to $99.2 \%$ at $18: 00 \mathrm{~h}$.

Temperatures in the Vapor cave ranged between $27.2^{\circ} \mathrm{C}$, recorded at $08: 00 \mathrm{~h}$, to $31.0^{\circ} \mathrm{C}$ noted at $13: 00 \mathrm{~h}$ (Fig. 7). The highest temperatures were 28.9, 31.0 and $29.5^{\circ} \mathrm{C}$ recorded at $11: 00 \mathrm{~h}, 13: 00 \mathrm{~h}$ and $15: 00 \mathrm{~h}$, respectively, while the lowest temperatures were 27.2 ,

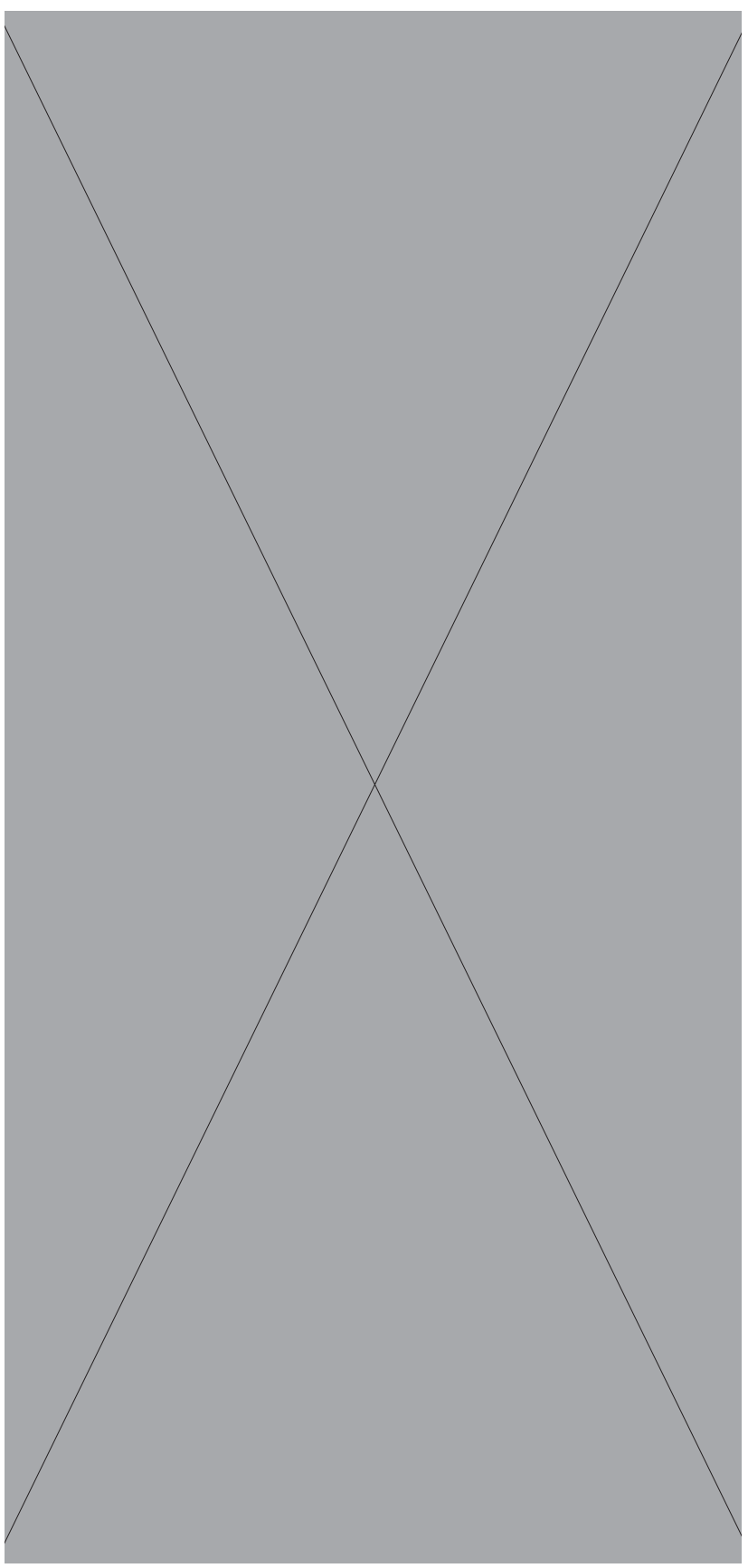

Fig. 5. Light micrographs [scale bar: $10 \mu \mathrm{m}$ ] of Scytonema julianum.

$27.5,28.1,29.1$ and $27.4^{\circ} \mathrm{C}$ noted at 08:00h, 10:00h, 12:00h, 14:00h and 18:00h, respectively.

Nighttime nitrogen fixation varied from 65.1 to $120.6 \mathrm{nmol}$ of $\mathrm{C}_{2} \mathrm{H}_{4} \mathrm{~m}^{-2} \mathrm{~s}^{-1}$ (Fig. 6) and nitrogenase activity was graphically depicted as a zigzagging line. At 08:00h, a value of $79.2 \mathrm{nmol}$ of $\mathrm{C}_{2} \mathrm{H}_{4} \mathrm{~m}^{-2} \mathrm{~s}^{-1}$ was noted, which rose to $120.6 \mathrm{nmol}$ of $\mathrm{C}_{2} \mathrm{H}_{4} \mathrm{~m}^{-2} \mathrm{~s}^{-1}$ at 10:00h. After this time, it dropped to $78.3 \mathrm{nmol}^{-1} \mathrm{C}_{2}$ $\mathrm{H}_{4} \mathrm{~m}^{-2} \mathrm{~s}^{-1}$ at 11:00h. Nitrogenase activity started rising again to reach $94.4 \mathrm{nmol}$ of $\mathrm{C}_{2} \mathrm{H}_{4} \mathrm{~m}^{-2} \mathrm{~s}^{-1}$ at $12: 00 \mathrm{~h}$ and then dropped to $75.8 \mathrm{C}_{2} \mathrm{H}_{4} \mathrm{~m}^{-2} \mathrm{~s}^{-1}$ at 13:00h. Finally, at 14:00h it rose to $97.3 \mathrm{C}_{2} \mathrm{H}_{4} \mathrm{~m}^{-2} \mathrm{~s}^{-1}$ at 15:00h, from which time nitrogenase activity descended to reach a minimum value of 65.1 to $120.6 \mathrm{nmol}$ of $\mathrm{C}_{2} \mathrm{H}_{4} \mathrm{~m}^{-2} \mathrm{~s}^{-1}$ at $17: 00 \mathrm{~h}$. 


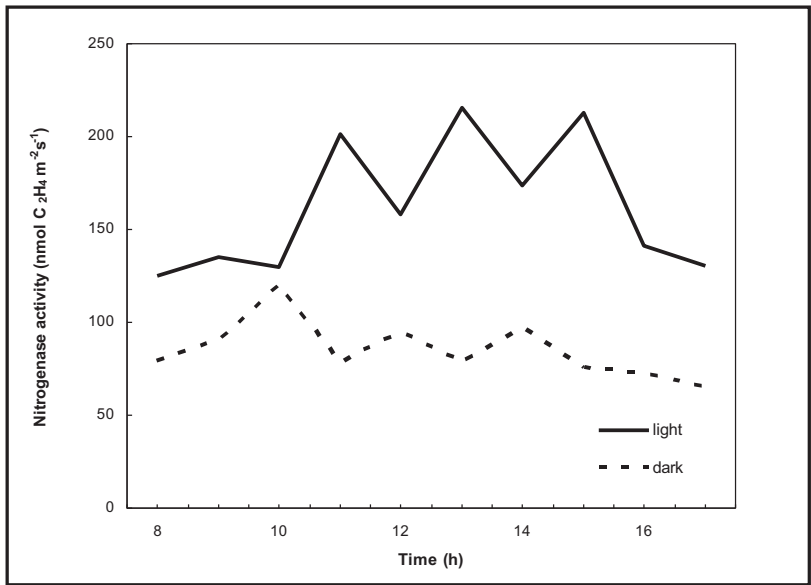

Fig. 6. Nitrogenase activity by Scytonema julianum (light and dark) in Vapor cave.

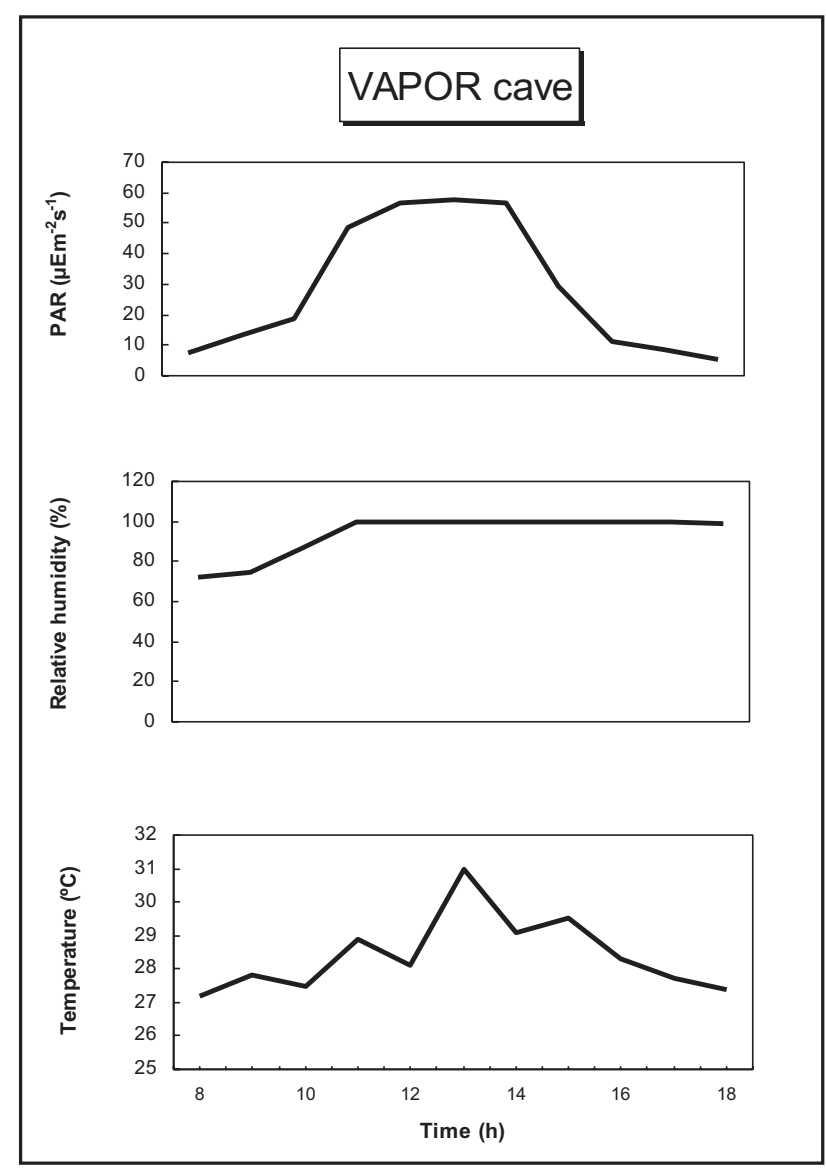

Fig. 7. PAR (Photosynthetically active radiation), temperature and relative humidity from sunrise to sunset in Vapor cave from a cyanobacterial mat of Scytonema julianum.

\section{DISCUSSION}

Nitrogenase activity by Scytonema julianum recorded in the Vapor cave over a 24-h period ranged from 129.9 to $215.7 \mathrm{nmol}$ of $\mathrm{C}_{2} \mathrm{H}_{4} \mathrm{~m}^{-2} \mathrm{~s}^{-1}$. These values are very close to those obtained for the Calothrix genus: $284 \mathrm{nmol}$ of $\mathrm{C}_{2} \mathrm{H}_{4} \mathrm{~m}^{-2} \mathrm{~s}^{-1}$ in tropical environments (Jones, 1992), where similar relative humidity and temperature conditions to those in the Vapor cave were registered.

If we compare the aforementioned values with the mean $28.2 \mathrm{nmol}$ value of $\mathrm{C}_{2} \mathrm{H}_{4} \mathrm{~m}^{-2} \mathrm{~s}^{-1}$ recorded in Scytonema sp. crusts from semi-arid areas of the U.S.A. (Jeffries et al., 1992), we notice a vast difference, despite previously rehydrating samples, which confirms the importance of a high, constant relative humidity in the nitrogen fixation process, which also occurs in the Vapor cave.

We also noted that the greater the light intensity at the Vapor cave study site, the higher the nitrogenase activity. This coincides with the results of Dodds (1989), even to the point that the times the highest nitrogenase activities were recorded coincide with the maximum PAR, temperature and relative humidity values.

Ethylene nighttime production by Scytonema julianum was between 65.1 and $120.6 \mathrm{nmol}$ of $\mathrm{C}_{2} \mathrm{H}_{4} \mathrm{~m}^{-2} \mathrm{~s}^{-1}$. These values were lower than those obtained in the daytime, which occurred with all the heterocysted cyanobacteria. Although these prokaryotes are considered totally photoautotroph organisms, some may grow in the darkness at a slower rate (Stewart, 1973; Jones, 1992).

Temperature inside the Vapor cave changed in accordance with the daytime or nighttime nitrogenase activity. When temperatures were lower, nitrogenase activity dropped, which is clearly demonstrated in the daytime when ethylene production dropped sharply as temperatures lowered, and again increased at higher temperatures. The exact opposite took place with nighttime nitrogen fixation as nitrogenase activity dropped at higher temperatures, and increased with lower temperatures.

Nitrogenase activity by Scytonema julianum was roughly 30 times higher than that of Scytonema mirabile, which also grew in a similar environment (Asencio \& Aboal, 2010), due to the characteristics of each site. The Andragulla cave was $2.0 \mathrm{~m}$ deep, 2.0 $\mathrm{m}$ high and $6.0 \mathrm{~m}$ wide. Its lack of depth meant that the microclimate was very similar to that experienced externally, which explained its extreme PAR (0.5$\left.582.7 \mu \mathrm{E} . \mathrm{m}^{-2} \cdot \mathrm{s}^{-1}\right)$, temperature $\left(1.5-20.3{ }^{\circ} \mathrm{C}\right)$ and relative humidity (24.0-79.9\%) winter values. The Vapor cave, however, was very deep so it was isolated from external influences. Therefore, its PAR values remained constant and it had very high temperature and relative humidity values.

The first ever daytime and nighttime nitrogen fixation values by Scytonema julianum recorded in the Vapor cave differed considerably, but coincided with Calothrix in tropical environments (Jones, 1992). This was likely due to the energy reserves stored during photosynthesis being exhausted and used in the dark phase, which occurred with Nostoc in Californian streams (Horne \& Carmiggelt, 1974). This fact suggests that Scytonema julianum, like other tropical terrestrial cyanobacteria (Jones, 1981, Saino \& Hattori, 1978), preferred high-levels of sunlight which could substantially contribute to the overall nitrogen cycle in $\mathrm{N}$-poor environments, such as cave entrances and other lighted areas.

\section{ACKNOWLEDGEMENTS}

We sincerely thank J.J. Ruiz de Almirón for his help in the field, H. Warburton for his assistance with the 
English version of the text and Dr. D.E. Northup and an anonymous reviewer for their comments on the manuscript.

\section{REFERENCES}

Aboal M., Asencio A.D. \& Prefasi M., 1994 - Studies on cave cyanophytes from southeastern Spain: Scytonema julianum Richter. Archiv für Hydrobiology/ Algological Studies, 75: 31-36.

Antonopoulou S., Oikonomou A., Karantonis H.C., Fragopoulou E. \& Pantazidou A., 2002 - Isolation and structural elucidation of biologically active phospholipids from Scytonema julianum (Cyanobacteria). Biochemical Journal, 367: 287-293.

Antonopoulou S., Karantonis H.C., Nomikos T., Oikonomou A., Fragopoulou E. \& Pantazidou A., 2005 - Bioactive polar lipids from Chroococcidiopsis sp. (Cyanobacteria). Comparative Biochemistry and Physiology-B Biochemistry and Molecular Biology, 142: $269-282$.

Asencio A.D. \& Aboal M., 2010 - In situ nitrogen fixation by cyanobacteria at the Andragulla cave (Spain). Journal of Cave and Karst Studies, 72(3): in press.

Bellezza S., Albertano P., De Philippis R. \& Paradossi G., 2006 - Exopolysaccharides of two cyanobacterial strains from Roman hypogea. Geomicrobiology Journal, 23: 301-310.

Bothe H., 1982 - Nitrogen fixation. In: Carr, N.G. \& Whiton, B.A. (Eds), The Biology of Cyanobacteria. University of California Press, Berkeley, 87-104.

Couté A. \& Bury E., 1988 - Ultrastructure d'une cyanophycée aérienne calcifiée cavernicole: Scytonema julianum (Frank) Richter (Hormogonophycideae, Nostocales, Scytonemataceae). Hydrobiologia, 160: 219-239.

Dodds W.K., 1989 - Microscale vertical profiles of $N_{2}$ fixation, photosynthesis, $\mathrm{O}_{2}$, chlorophyll $a$ and light in a cyanobacterial assemblage. Applied and Environmental Microbiology, 55: 882-886.

Friedman E.I., 1973 - Scanning electron microscopy of three lime encrusting aerophytic blue-green algae. Journal of Phycology, 9: 17.

Griffiths M.S.H., Gallon J.R. \& Chaplin A. E., 1987 - The diurnal pattern of dinitrogen fixation by cyanobacteria in situ. New Phytologist, 107: p. 649-657.
Hill C.A., 1987 - Geology of Carlsbad Cavern and other caves in the Guadalupe Mountains, New Mexico and Texas: Socorro, N.M. New Mexico Bureau of Mines and Mineral Resources Bulletin, 117: 150.

Hoffmann L., 1989 - Algae of terrestrial habitats. Botanical Review, 55: 77-105.

Hoffmann L., 1992 - Variability in the crystal morphology of calcified terrestrial Scytonema populations (Cyanobacteria, Cyanophyceae). Geomicrobiology Journal, 10: 59-64.

Horne A.J. \& Carmiggelt C.J.W., 1974 - Algal nitrogen fixation in Californian streams: seasonal cycles. Freshwater Biology, 5, 461-470.

Houssman D.C., Powers H.H., Collins A.D. \& Belnap J., 2006 - Carbon and nitrogen fixation differ between successional stages of biological soil crusts in the Colorado Plateau and Chihuahuan Desert. Journal of Arid Environments, 66: 620-634.

Jeffries D.L., Klopatek J.M., Link S.O. \& Bolton H.Jr., 1992 - Acetylene reduction by cryptogamic crusts from a blackbrush community as related to resaturation and dehydration. Soil Biology and Biochemistry, 24: 11011105.

Jones K., 1981 - Diurnal acetylene reduction by mats of blue-green algae in sub-tropical grassland: use of shortterm and long-term assays. New Phytology, 88: 73-78.

Jones K., 1992 - Diurnal nitrogen fixation in tropical marine cyanobacteria: a comparison between adjacent communities of non-heterocystous Lyngbya $s p$. and heterocystous Calothrix $s p$. British Phycological Journal, 27:107-118.

Ruíz de Almirón J.J., 1998 - La sima del Vapor. Subterránea, 9: 36-43.

Saino T. \& Hattori A., 1978 - Dial variation in nitrogen fixation by a marine blue-green alga, Trichodesmium thiebautii. Deep Sea Research, 25: 1259-1263.

Stewart W.D.P., 1973 - Nitrogen fixation. In Carr, N.G. $\&$ Whiton, B.A. (Eds), The Biology of Blue-Green Algae. Blackwell Scientific Publications, Oxford: 260-278.

Zielke M., Solheim B., Spjelkavik S. \& Olsen R. A., 2005 - Nitrogen fixation in the high Arctic: role of vegetation and environmental conditions. Arctic, Antarctic and Alpine Research, 37: 372-378. 